\title{
Bruk av metformin ved polycystisk ovarie-syndrom
}

\author{
Polycystisk ovarie-syndrom rammer kvinner i fertil alder og skal \\ primært behandles med kostholds- og livsstilstiltak, spesielt når det \\ er assosiert med overvekt. Det er imidlertid økende dokumentasjon \\ på at metformin kan ha gunstig effekt på mange av syndromets \\ manifestasjoner. Norske leger bør derfor ha kjennskap til metformin- \\ behandling ved polycystisk ovarie-syndrom.
}

Se også kunnskapsprøve på www.tidsskriftet.no/quiz

Interessen for og kunnskapene om polycystisk ovarie-syndrom (PCOS) er økende selv om syndromet fortsatt på mange vis er gåtefullt og årsaken fortsatt ukjent. Det er imidlertid klart at insulinresistens og hyperinsulinemi står sentralt i patogenesen (1). Trolig derfor har metformin, på samme måte som kostholds- og livsstilsintervensjon, som utgjør grunnbehandlingen av disse pasientene, vist seg å ha effekt på mange av de kliniske manifestasjonene $(2,3)$. Dette gjelder kanskje spesielt når pasientene er moderat overvektige og insulinresistente. Det er min kliniske erfaring at metformin også ofte gir effekt hos normalvektige uten betydelig hyperinsulinemi. Til tross for at polycystisk ovarie-syndrom ikke er noen godkjent indikasjon, bør norske leger ha kunnskap om metforminbehandling ved dette syndromet.

I denne artikkelen ser jeg derfor nærmere på hvilken plass metformin har i behandlingen av de enkelte manifestasjoner ved polycystisk ovarie-syndrom og hvordan behandlingen i allmennpraksis kan foregå.

\section{Materiale og metode}

Artikkelen bygger på forfatterens egen erfaring og et usystematisk søk i PubMed med et skjønnsomt utvalg artikler.

\section{Polycystisk ovarie-syndrom}

For å stille diagnosen polycystisk ovarie-syndrom må to av tre følgende kriterier oppfylles:

- Polycystiske ovarier med minst 12 2-9 $\mathrm{mm}$ store follikler på hver side eller ovarialvolum $>10 \mathrm{ml}$

- Klinisk hyperandrogenisme (hirsutisme, akne, mannlig hårtap) eller biokjemisk hyperandrogenisme (testosteron, fritt testosteron, androstendion)

- Oligo- eller anovulasjon (syklus $>35$ dager eller $<10$ sykluser/år) (4)

$5-10 \%$ av kvinner i fertil alder har dette syndromet, som viser tendens til familiær opphopning.
Den økte ovariale syntesen av androgen fører til hirsutisme, akne, menstruasjonsforstyrrelser og infertilitet. Insulinresistens og den kompensatoriske hyperinsulinemien antas å være en sentral patogenetisk mekanisme, først og fremst ved at insulin, i nærvær av LH, stimulerer androgensyntesen i ovariene. Insulinresistensen medfører også økt forekomst av metabolsk syndrom og diabetes type 2 er flerdoblet. Trolig vil $10 \%$ kvinnene ha utviklet diabetes type 2 når de når menopausen.

Navnet hyperandrogent metabolsk syndrom har vært foreslått siden kvinner kan ha polycystisk ovarie-syndrom uten å ha polycystiske ovarier. For tiden diskuteres det om økt androgenpåvirkning i forsterlivet kan være den sentrale bakenforliggende patogenetiske mekanismen som gir både ovarial hyperandrogenisme og insulinresistens hos den voksne kvinnen (5).

\section{Metformins effekt på hyperandrogenisme}

Generelt synes metformin å gi en moderat reduksjon av sirkulerende nivå av testosteron, fritt testosteron, androstendion og dehydroepiandrosteronsulfat (DHEAS). Sannsynligvis er dette først og fremst sekundært til redusert insulinforsterket androgensyntese i ovariene, men også i binyrene. I tillegg synes det som metformin har en direkte hemmende effekt på flere trinn i ovarienes androgensyntese. Teoretisk skulle dette tilsi at androgennivåene blir redusert selv om det også finnes gode randomiserte studier som ikke har vist noen sikker virkning $\mathrm{i}$ så henseende $(1,6,7)$. Dette kan ha sammenheng med at polycystisk ovarie-syndrom kan ha flere undergrupper og at de studerte pasientpopulasjoner er forskjellige.

Metformin gir også en liten, men sikker effekt på hirsutisme. Den er imidlertid ikke påvisbar hos alle og sammenliknbar med den man oppnår med p-pillebehandling (7). Det er viktig å informere pasientene om at effekten på hirsutisme kommer gradvis over måneder (halvt år). P-pille og metformin kan kombineres når hirsutisme er hovedproblemstillingen. Effekten av slik kombinasjonsbehandling er imidlertid ikke dokumentert. Effekten av metformin på annen klinisk hyperandrogenisme er lite undersøkt.

\section{Metformins effekt på menstruasjon og fruktbarhet} Ved uregelmessig menstruasjon kan metformin normalisere menstruasjonssyklus og gjøre anovulatoriske sykler ovulatoriske. Selv amenoreiske kvinner kan få normalisering eller nær normalisering av syklus (3). Forfatterens egen kliniske erfaring tilsier at man kan ha betydelig effekt på menstruasjonsforstyrrelser uten sikker reduksjon av androgen. og at menstruasjonsforstyrrelser kan bedres også hos kvinner med polycystisk ovarie-syndrom uten holdepunkter for insulinresistens.

Metformin synes å være like effektivt som klomifen i monoterapi når det gjelder å oppfylle barneønske hos tidligere ubehandlede kvinner med polycystisk ovarie-syndrom $(3,8)$. Metformin gir antakelig lavere forekomst av flerlingsvangerskap, men til gjengjeld fører den ikke til ovulasjon så tidlig som klomifen (3). Andre mener imidlertid at klomifen er mer effektivt (2). Hos klomifenresistente kvinner øker metformin graviditetsraten i kombinasjon med klomifen. Fremdeles er dokumentasjonen mangelfull og til dels sprikende (3).

Det er viktig å informere kvinner med polycystisk ovarie-syndrom som begynner med metformin, om muligheten for graviditet og muligheten å kombinere preparatet

\section{Hovedbudskap}

- Kost- og livsstilsrelatert behandling er førstevalg ved polycystisk ovariesyndrom, spesielt når det er assosiert med overvekt

- Metformins antatte virkningsmekanisme er å redusere insulinresistens og hyperinsulinemi og derved redusere androgensyntese i eggstokkene

- Metformin synes å ha like god effekt på ovulasjonsinduksjon som klomifen hos kvinner med polycystisk ovariesyndrom

- Metformin bør unngås under graviditet 


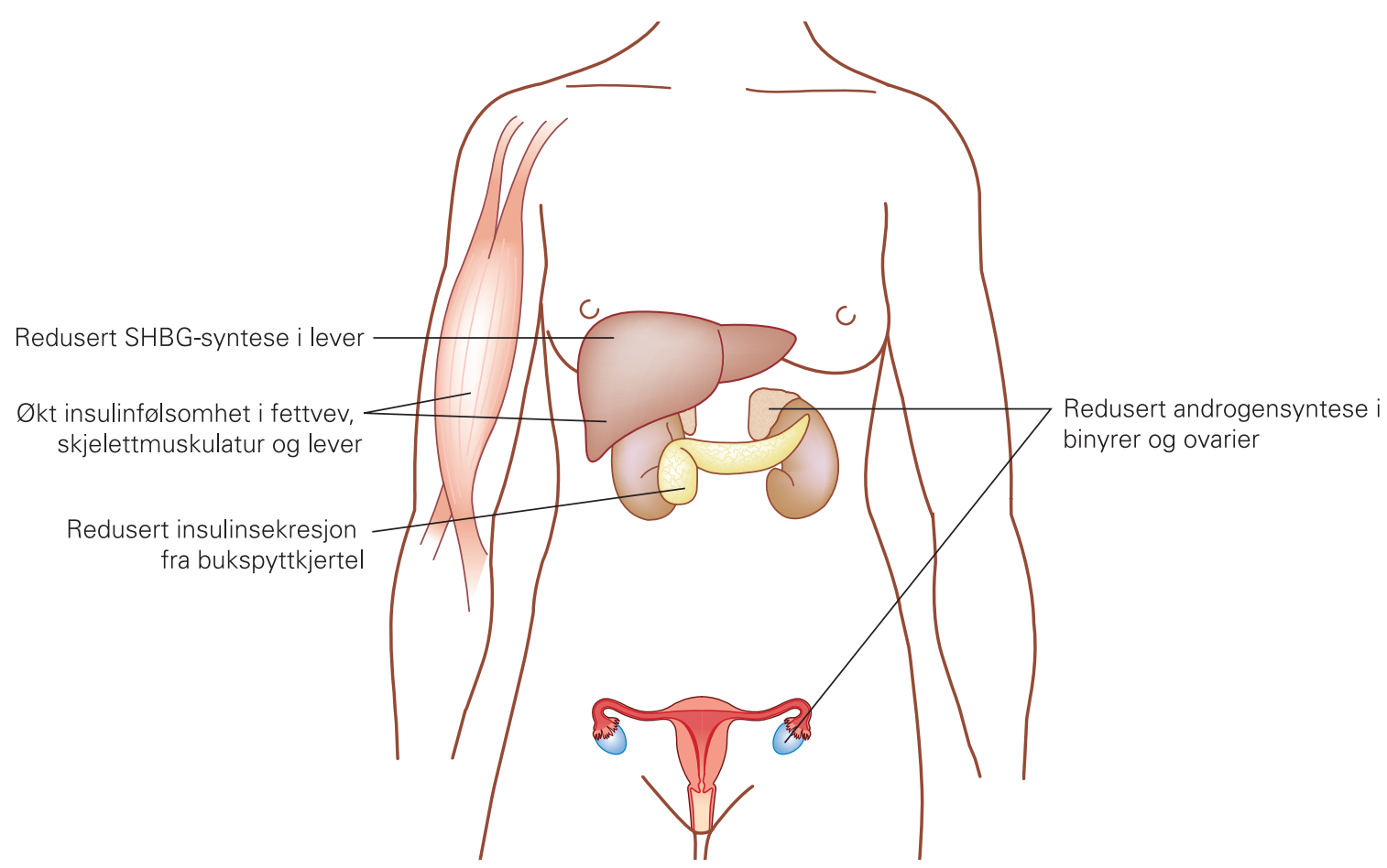

Figur 1 Direkte og indirekte metformineffekt ved polycystisk ovarie-syndrom. Hvorvidt metformin også virker på hypotalamisk/hypofysært nivå, er ikke avklart. Det er mulig effekten gjelder kun for subgrupper. SHBG = kjønnshormonbindende globulin

med en p-pille eller annen sikker antikonsepsjon dersom graviditet er uønsket.

Dersom infertilitet er problemstillingen, er det hos overvektige viktig å kombinere metformin med en hypokalorisk diett for å oppnå vektreduksjon. I tillegg bør det oppmuntres til fysisk aktivitet uansett kroppsvekt. Jeg pleier å si til slike pasienter at noen få kilos vektreduksjon kan utgjøre forskjellen mellom graviditet og barnløshet, at metformin gjør det litt mindre vanskelig å gå ned i vekt og synes å ha en egen effekt i ovariene som fremmer eggløsning.

\section{Metabolske effekter}

Generelt synes metformin å gi en lett vektreduksjon hos overvektige kvinner med polycystisk ovarie-syndrom samtidig som livvidden reduseres, særlig i kombinasjon med kostholds- og livsstilsintervensjon. Effekten er imidlertid ikke stor og har vært fraværende i noen studier (3). Vekteffekten av metformin er muligens doserelatert og er ikke sekundær til gastrointestinale bivirkninger.

Det er også holdepunkter for at metformin reduserer systolisk blodtrykk, senker LDLkolesterolnivået og bedrer endotelial dysfunksjon hos kvinner med dette syndromet. Dessverre foreligger ikke langtidsstudier som kan avklare effekten av metformin på forekomsten av diabetes type 2 og kardiovaskulær sykdom. Men gitt den betydelige overhyppigheten av metabolsk syndrom og diabetes type 2 samt at metformin hos personer med nedsatt glukosetoleranse forebygger diabetes type 2 , er det rimelig å anta samme effekt ved langtidsbehandling av kvinner med polycystisk ovarie-syndrom. Selv om kun få og kortvarige studier er utført, er dette også en grunn til primært å velge metformin i stedet for perorale antikonsepsjonsmidler som tenderer til å øke insulinresistensen. Kombinasjonsbehandling med metformin kan godt benyttes. Langvarige studier som avklarer om dette medfører forskjellig forekomst av kliniske endepunkter, mangler.

\section{Svangerskap og amming}

Polycystisk ovarie-syndrom medfører en betydelig økt forekomst av svangerskapsdiabetes, trolig i størrelsesorden 20-30\% (9). Disse kvinnene bør derfor følges spesielt gjennom svangerskapet, helst med repeterte perorale glukosebelastninger. Ved svangerskapsdiabetes behandles de foreløpig med insulin etter vanlige retningslinjer for svangerskapsdiabetes.

Kvinner med slikt syndrom har betydelig $ø \mathrm{kt}$ forekomst av en rekke svangerskapskomplikasjoner (9). Observasjonsstudier antyder at metformin brukt under svangerskap kan redusere forekomsten av aborter og flere andre svangerskapskomplikasjoner. En pågående norsk multisenterstudie (PregMetstudien) vil forhåpentligvis avklare dette. Imens må metformin til gravide med polycystisk ovarie-syndrom anses som eksperimentell behandling og kun benyttes i kliniske studier (1). Det er viktig i denne sammenheng at metformin passerer fritt over placenta og at fosteret eksponeres for samme metforminkonsentrasjoner som mor (10). Langtidseffekten av intrauterin metformineksponering er ukjent. Kvinner som blir gravide med metformin, bør derfor inntil sikrere data foreligger, seponere behandlingen straks graviditeten er erkjent.

Overgangen av metformin til morsmelk er svært liten. Det er ikke påvist negative effekter på barna av ammende mødres metforminbruk (11).

\section{Praktisk metforminbruk}

Start med en liten dose, metformin 500-850 mg daglig, akkurat som ved diabetes type 2 . Øk deretter med en ukes mellomrom opp til 2 500-3 $000 \mathrm{mg}$ daglig. Ved døgndose over $1000 \mathrm{mg}$ bør den deles minst i to. Ved å ta metformin med maten minskes tendensen til kvalme, oppkast og gastrointestinalt ubehag. I løpet av noen dager eller uker vil ofte slike bivirkningene opphøre eller kunne tolereres. I motsatt fall reduseres dosen ett trinn. Det er viktig å informere om at forbigående gastrointestinalt ubehag ofte inntrer. Kun et fåtall pasienter tolererer overhodet ikke metformin.

Siden dette stort sett dreier seg om yngre kvinner, er kontraindikasjonene redusert nyrefunksjon, redusert leverfunksjon og hjertesvikt sjelden en aktuell problemstilling. Nyrefunksjonen behøver derfor heller ikke følges regelmessig under behandlingen hos disse yngre kvinnene. Det bør utvises forsiktighet ved alvorlig astma.

Effekten av behandlingen evalueres etter tre til seks måneder. Er det da god klinisk effekt, kan man vurdere å redusere dosen. 
Er infertilitet hovedindikasjonen, bør man vurdere å kontinuere største tolerable dose siden ingen data om dose-respons-effekt foreligger. Man skal også være klar over at det er en tendens til at polycystisk ovariesyndrom «brenner ut» når kvinnen blir eldre. Dette medfører bl.a. fallende androgennivå, mer regelmessig menstruasjon og at tidligere infertile kvinner kan bli gravide. Etter noen års metforminbehandling er det derfor uansett fornuftig å forsøke dosereduksjon eller seponering.

\section{Konklusjon}

Metformin er ikke det ideelle medikament ved polycystisk ovarie-syndrom, siden det virker klart utilfredsstillende på mange av manifestasjonene. Medikamentet virker imidlertid inn på insulinresistens og hyperinsulinemi, som antas å stå sentralt i patogenesen for polycystisk ovarie-syndrom, samtidig som det er velprøvd fra decenniers bruk ved diabetes type 2 . Det er påfallende hvor mange kvinner med polycystisk ovariesyndrom som ønsker å fortsette behandlingen med metformin selv når det er vanskelig å påvise kliniske effekter. Effekten utover ett år er ikke studert ved polycystisk ovarie-syndrom. Det samme gjelder alle andre aktuelle medikamenter. Sammen med kostholds- og livsstilsintervensjon, som alltid bør være en del av terapien, er metformin likevel et godt alternativ.

\section{Sven M. Carlsen}

sven.carlsen@ntnu.no

Institutt for kreftforskning og molekylærmedisin Norges teknisk-naturvitenskapelige universitet og

Avdeling for endokrinologi

St. Olavs hospital

7006 Trondheim

Oppgitte interessekonflikter: Forfatteren er involvert i flere store pågående forskningsprosjekter med metformin ved forskjellige problemstillinger ved polycystisk ovarie-syndrom. I to av prosjektene fås metformin og placebo vederlagsfritt fra Weifa. Ett prosjekt støttes økonomisk av Serono Nordic

\section{Litteratur}

1. Dunaif A. Drug insight: insulin-sensitizing drugs in the treatment of polycystic ovary syndrome a reappraisal. Nat Clin Pract Endocrinol Metab 2008; 4: 272-83.

2. Mathur R, Alexander CJ, Yano J et al. Use of metformin in polycystic ovary syndrome. Am J Obstet Gynecol 2008; 199: 596-609

3. Palomba S, Falbo A, Zullo F et al. Evidence-based and potential benefits of metformin in the polycys- tic ovary syndrome: a comprehensive review. Endocr Rev 2009; 30: 1-50.

4. The Rotterdam ESHRE/ASRM-Sponsored PCOS consensus workshop group. Revised 2003 consensus on diagnostic criteria and long-term health risks related to polycystic ovary syndrome (PCOS). Hum Reprod 2004; 19: 41-7.

5. Xita N, Tsatsoulis A. Review: fetal programming of polycystic ovary syndrome by androgen excess: evidence from experimental, clinical, and genetic association studies. J Clin Endocrinol Metab 2006 91: 1660-6

6. Nestler JE. Metformin for the treatment of the polycystic ovary syndrome. N Engl J Med 2008; 358: $47-54$

7. Cosma M, Swiglo BA, Flynn DN et al. Clinical review: insulin sensitizers for the treatment of hirsutism: a systematic review and metaanalyses of randomized controlled trials. J Clin Endocrinol Metab 2008; 93: 1135-42.

8. Moll E, van der Veen F, van Wely M. The role of metformin in polycystic ovary syndrome: a systematic review. Hum Reprod Update 2007; 13: 527-37.

9. Boomsma CM, Eijkemans MJ, Hughes EG et al. A meta-analysis of pregnancy outcomes in women with polycystic ovary syndrome. Hum Reprod Update 2006; 12: 673-83.

10. Vanky E, Zahlsen K, Spigset 0 et al. Placental passage of metformin in women with polycystic ovary syndrome. Fertil Steril 2005; 83: 1575-8.

11. Feig DS, Briggs GG, Koren G. Oral antidiabetic agents in pregnancy and lactation: a paradigm shift? Ann Pharmacother 2007: 41: 1174-80.

Manuskriptet ble mottatt 12.12. 2008 og godkjent 20.5. 2009. Medisinsk redaktør Anne Kveim Lie. 